\title{
Peningkatan Pendapatan Peternak Melalui Penggunaan Pakan Sakura Blok pada Sapi Perah di Gapoktan Sumber Mulya Kecamatan Kabawetan Kabupaten Kepahiang Propinsi Bengkulu
}

\author{
Increasing Revenue of Farmers through the Use of Sakura Feed Block on Dairy Cow in \\ Gapoktan SumberMulya District Kabawetan District Kepahiang Province of Bengkulu \\ Province
}

\author{
Jarmuji $^{1}$, E. Silvia ${ }^{2}$, dan E. Sulistyowati ${ }^{1}$ \\ ${ }^{1}$ Jurusan Peternakan Fakultas Pertanian Universitas Bengkulu \\ ${ }^{2}$ Jurusan Teknologi Pertanian Fakultas Pertanian Universitas Bengkulu \\ Jl.W.R. Supratman, Kandang Limun, Bengkulu 38125 \\ email: jarmuji_78@yahoo.com
}

\begin{abstract}
The demonstration plot was conducted for 2 months (60 days) using a Latin Square design with 4 treatments and four replications. Each treatment period is carried out for 15 days. The treatments in the demonstration plot were D0 (100\% natural grass), D1 (natural grass + Sakura block $300 \mathrm{gr} /$ day), D2 (natural grass and Sakura block $600 \mathrm{gr} / \mathrm{hr}$ ) and D3 (natural grass + Sakura block $900 \mathrm{gr} /$ day ). The demplot result showed that the highest dairy production was produced in dairy cows that received additional Sakura block of $600 \mathrm{gr} / \mathrm{head} /$ day which was 10.87 liters / day, followed by 10.12 liters / day in dairy cows with Sakura block of $900 \mathrm{gr} / \mathrm{head}$ / day and 9.09 liters / day in groups of cattle fed Sakura block $300 \mathrm{gr} /$ head / day. While those who did not get additional Sakura block had an average milk production only 7.25 liter / day. Based on income analysis, the highest income was obtained in dairy cow receiving block of $600 \mathrm{gr} /$ head / day that was Rp.8.517.167, - / month for four cows. While groups of livestock that did not get additional block Sakura feed only generated a net worth of Rp.4.986.667, -. While those fed additional block Sakura of $300 \mathrm{gr} / \mathrm{head} / \mathrm{day}$ and $900 \mathrm{gr} / \mathrm{head} /$ day each obtained a net income of Rp.6.579.167, - and Rp.7.365.167, - .
\end{abstract}

Key words: dairy cow FH, milk production, Sakura block, profit

\begin{abstract}
ABSTRAK
Pelaksanaan demplot dilakukan selama 2 bulan (60 hari) dengan menggunakan metode Bujur Sangkar Latin dengan 4 perlakuan dan empat ulangan. Setiap periode perlakuan dilakukan selama 15 hari. Perlakuan dalam demplot antara lain D0 (100\% rumput alam), D1 (rumput alam + Sakura blok 300 gr/hari), D2 (rumput alam dan Sakura blok $600 \mathrm{gr} / \mathrm{hr}$ ) dan D3 (rumput alam + Sakura blok $900 \mathrm{gr} / \mathrm{hari}$ ). Hasil demplot menunjukkan bahwa produksi susu tertinggi dihasilkan pada ternak sapi perah yang mendapat pakan tambahan Sakura blok plus 600 gr/ekor/hari yaitu 10,87 liter/hari, diikuti dengan 10,12 liter/hari pada kelompot ternak sapi perah yang mendapat Sakura blok 900 gr/ekor/hari dan 9,09 liter/hari pada kelompok ternak yang mendapat pakan Sakura blok 300 gr/ekor/hari. Sementara yang tidak mendapat pakan tambahan Sakura blok plus rata-rata produksi susu hanya 7,25 liter/hari. Berdasarkan hasil analisis pendapatan, pendapatan tertinggi diperoleh pada ternak sapi perah yang mendapat pakan tambahan 600 gr/ekor/hari yaitu Rp.8.517.167,-/bulan untuk empat ekor sapi. Sementara kelompok ternak yang tidak mendapatkan pakan tambahan Sakura blok hanya menghasilkan laba bersih sebesar Rp.4.986.667,-- Sapi perah yang diberi pakan tambahan Sakura blok sebesar 300 gr/ekor/hari dan 900 gr/ekor/hari masing-masing memperoleh laba bersih sebesar Rp.6.579.167,- dan Rp.7.365.167,-.
\end{abstract}

Kata kunci: sapi perah FH, produksi susu, Sakura blok, laba

\section{PENDAHULUAN}

Usaha sapi perah merupakan salah satu sektor usaha peternakan yang banyak memberi manfaat dalam memenuhi kebutuhan pangan yang terus meningkat dan pencitaan lapangan kerja. Kondisi geografis, ekologi dan kesuburan lahan di beberapa wiayah di Indonesia memiliki karakteristik yang cocok untuk usaha sapi 
perah. Produksi susu saat ini baru dapat memenuhi $30 \%$ permintaan konsumsi susu nasional, sisanya $70 \%$ berasal dari impor. Kondisi ini tentu menimbulkan beberapa kerugian yang cukup besar seperti terkurasnya devisa negara, hilangnya lapangan pekerjaan, tidak termanfaatkan sumber daya alam dan hilangnya potensi yang seharunya pemerintah terima dari sektor pajak.

Kabupaten Kepahiang merupakan salah satu wilayah di Propinsi Bengkulu yang cocok untuk pengembangan sapi perah. Secara geografis kabupaten Kepahiang merupakan daerah pegunungan yang memiliki suhu lingkungan dingin (15$24^{0} \mathrm{C}$ ) dan memiliki kekayaan alam berupa pakan ternak seperti rumput alam, limbah pertanian dan limbah indutri pertanian yang melimpah untuk pengembangan sapi perah. Pengembangan sapi perah di Kabupaten Kepahiang dimulai sejak tahun 2008 tepatnya di Gabungan Kelompok Tani (Gapoktan) Sumber Mulya di Desa Sukasari Kecamatan Kabawetan. Gapoktan Sumber Mulya berdiri sejak tahun 2008 dengan anggota sebanyak 87 orang kepala keluarga.

Sapi perah merupakan komoditi unggulan yang dikembangkan pemerintah daerah di Desa Suka Sari tepatnya di kelompok Gapoktan Sumber Mulya. Tujuan pengembangan usaha sapi perah di Kabupaten Kepahiang adalah untuk menghasilkan susu segar guna memenuhi kebutuhan masyarakat, penciptakan lapangan kerja dan pemanfaatan sumber daya alam terutama hijauan dan limbah pertaninan yang melimpah. Pengembangan sapi perah juga merupakan salah satu usaha yang diharapkan berkembang baik dan menguntungkan sehingga dapat dijadikan percontohan pada anggota masyarakat lainnya.

Namun demikian, sampai saat ini produksi susu sapi perah di Gapoktan Sumber Mulya \pm 7,5 liter/hari, sementara produksi susu sapi perah dapat mencapai 15-20 liter/hari (BSNI, 2008). Secara kelembagaan peningkatan produksi dapat dilakukan dengan cara membentuk suatu koperasi, dimana saat ini $90 \%$ produksi susu sapi perah dihasilkan oleh koperasi (Yusdja dan Rusastra, 2001). Meskipun demikian koperasi masih perlu banyak pembenahan salah satunya adalah status peternak yang tergabung dalam anggota, dimana saat ini anggota hanya berfungsi saat menjual susu segar dan membayar iuran wajib serta iuran pokok, fungsi lain seperti fungsi kontrol dalam rapat sering kali tidak berjalan (Yusdja dan Sayuti, 2002).

Peternak yang tergabung dalam anggota koperasi hanya berkontribusi saat menjual susu Rendahnya produksi susu sapi perah menyebabkan kerugian finansial yang sangat besar bagi peternak sapi perah dan Pemerintah Daerah. Kerugian lain yang cukup besar adalah timbulkan rasa ketakutan dan trauma yang besar bagi masyarakat petani yang lain untuk mengembangkan sapi perah. Salah satu penyebab rendahnya produksi susu sapi perah di Gapoktan sumber yaitu jenis pakan yang diberikan hanya berupa hijauan dan ampas tahu. Peningkatan produksi susu sapi 
perah dapat dilakukan dengan pemberian pakan berupa konsentrat dan hijauan yang memiliki kandungan nutrisi tinggi (Makin, 2011).

Nurdin (2011) menambahkan, sapi perah dewasa membutuhkan pakan berupa hijauan sebanyak $10 \%$ dari bobot badan dan konsentrat sebanyak 2\% dari bobot badan, dan ketika sapi dewasa laktasi harus mendapat tambahan pakan sebanyak $25 \%$ dari biasanya. Sapi perah yang produksi susunya rendah juga dapat menurunkan kemampuan reproduksi seperti jarak kelahiran yang panjang, persentase beranak rendah dan meningkatkan resiko kematian induk dan pedet saat melahiran dan menurunkan laktosa, lemak dan protein pada air susu (Nurliyani, 2012). Santoso (2006) melaporkan bahwa pemberian pakan Sakura blok dapat meningkatkan pertambahan berat badan, konsumsi dan efisiensi pakan pada ternak kambing. Badarina (2003) menyatakan bahwa pemberian pakan suplemen Sakura blok mampu meningkatkan pertambahan berat bada pada ternak sapi yang diberi pakan basal rumput alam. Pemberian pakan suplemen Sakura blok juga mampu meningkatakan Pertambahan Bobot Badan pada Sapi Bali (Jarmuji et al., 2013) dan meningkatkan kecernaan pada sapi lokal Kaur (Jarmuji et al., 2017).

Sakura Blok merupakan pakan suplemen yang terbuat dari bahan-bahan local yang ketersediaannya cukup banyak seperti limbah pengrajin gula merah, dedak, jagung giling, sagu, urea garam dan lakta mineral. Sakura blok merupakan pakan suplemen yang kaya kandungan gizi seperti protein, energi dan mineral yang sangat dibutuhkan ternak. Bahan-bahan Sakura blok pada sapi perah dapat dimodifikasi seperti dengan penambahan bahan katuk dan kunyit.

\section{MATERI DAN METODE}

Demplot ini dilaksanakan di Gapoktan Sumber Mulya Kecamatan Kaba Wetan Kabupaten Kepahiang selama 2 bulan. Bahan - bahan yang digunakan adalah sapi perah FH laktasi kedua, Sakura blok yang terbuat dari bahan-bahan seperti dedak, gula merah, tepung jagung, tepung gaplek, urea, tsp, garam, tepung daun katuk dan tepung kunyit (Tabel 1) dan rumput alam. Peralatan yang digunakan dalam penelitian ini berupa alat pencetak Sakura blok, milk can, gelas ukur timbangan digital merk Ohaus SE, parang dan sabit. Kandang individu yang dilengkapi tepat pakan, ember, sapu lidi dan lampu pijar dan kandang kelompok. Pelaksanaan demplot dilakukan selama 2 bulan (60 hari) dengan menggunakan metode Bujursangkar Latin dengan 4 perlakuan dan empat ulangan.

Setiap periode perlakuan dilakukan selama 15 hari. Perlakuan dalam demplot antara lain D0 (demplot sapi perah yang hanya diberi pakan konvensional berupa rumput tanpa menggunakan Sakura blok), D1 (demplot sapi perah yang diberi pakan rumput dan Sakura blok 300 gr/hari), D2 (Demplot sapi perah yang diberi pakan rumput dan Sakura blok $600 \mathrm{gr} / \mathrm{hr}$ ) dan D3 (Demplot sapi perah yang diberi pakan rumput dan Sakura blok 900 gr/hari). 
Tabel 1. Komposisi bahan-bahan Sakura blok

\begin{tabular}{llccc}
\hline No. & \multicolumn{1}{c}{ Bahan baku } & $\begin{array}{c}\text { Formula } \\
(\%)\end{array}$ & $\begin{array}{c}\text { Harga } \\
\text { (kg/Rupiah) }\end{array}$ & $\begin{array}{c}\text { Biaya } \\
\text { /kilogram }\end{array}$ \\
\hline 1. & Gula merah (kelapa) & 32 & 15000 & 4800 \\
2. & Dedak & 30 & 2500 & 750 \\
3. & Ampas tahu & 25 & 1000 & 250 \\
4. & Urea & 3 & 3000 & 90 \\
5. & TSP & 1 & 6000 & 60 \\
6 & Garam & 2 & 3000 & 60 \\
9 & Mineral catlle & 2 & 20000 & 400 \\
10 & Top mix & 1 & 25000 & 250 \\
11 & Tepung daun katuk & 2 & 10000 & 200 \\
12 & Tepung kunyit & 2 & 5000 & 100 \\
\hline Jumlah & 100 & & Rp. 7.000,- \\
\hline
\end{tabular}

\section{Prosedur Demplot}

Rumput alam disediakan dalam bentuk bahan segar. Sakura blok dibuat dari campuran bahan-bahan seperti gula merah, dedak padi, jagung giling, tepung gaplek, urea, garam, TSP, mineral mix, Top mix, tepung daun katuk dan tepung kunyit (Tabel 1), pembuatannya bahan-bahan yang akan digunakan terlebih dahulu ditimbang, dicampur, gula merah dimasak kemudian dicampur kedalam bahan-bahan lain dan siap untuk dicetak dalam blok Pembuatan Sakura blok.

Pemberian pakan dilakukan dengan cara pemberian rumput alam dalam bentuk segar, sedangkan Sakura blok diberikan dalam bentuk blok. Pakan diberikan sebanyak 3,5\% bahan kering dari berat hidup untuk menjamin terpenuhinya kebutuhan zat makanan bagi ternak. Pemberian pakan dilakukan 2 kali sehari pukul 09.00 dan 17.00 dengan air minum tersedia setiap saat (ad libithum).

Variabel yang diamati dalam demplot ini adalah produksi susu harian (kg/ekor/hari), diukur dengan cara menimbang hasil susu pemerahan pagi dan sore dan kelayakan pendapatan (cash flow)
Data yang diperoleh dianalisis varian berdasarkan rancangan Bujur Sangkar Latin $4 \times 4$. Apabila terdapat perbedaan dilakukan uji lanjut dengan uji Duncan's Multiple Range Test (Yitnosumarto, 1993).

\section{HASIL DAN PEMBAHASAN}

Hasil yang diperoleh rata-rata produksi susu meningkat pada ternak yang diberi pakan tambahan Sakura blok (Tabel 2).

Tabel 2. Rataan produksi susu sapi perah (kg/ek/hari)

\begin{tabular}{llllll}
\hline \multirow{2}{*}{ Demplot } & \multicolumn{5}{c}{ Ulangan } \\
\cline { 2 - 6 } & \multicolumn{5}{c}{ Rataan } \\
\hline D0 & 6.48 & 8.53 & 8.22 & 6.58 & 7.45 \\
D1 & 9.60 & 8.45 & 9.47 & 9.87 & 9.34 \\
D2 & 12.34 & 12.13 & 9.66 & 10.59 & 11.17 \\
D3 & 10.79 & 10.28 & 10.28 & 10.28 & 10.40 \\
\hline
\end{tabular}

Keterangan: D0 (demplot sapi perah yang hanya diberi pakan rumput; D1; rumput dan Sakura blok 300 gr/hari; D2 (rumput dan Sakura blok $600 \mathrm{gr} / \mathrm{hr}$ ) dan D3 ( rumput dan Sakura blok $900 \mathrm{gr} / \mathrm{hari})$.

Hasil demplot selama dua bulan menunjukkan bahwa penambahan pakan Sakura blok pada sapi perah Gapoktan Sumber Mulya nyata meningkatkan produksi susu harian sapi perah. Rata-rata 
peningkatan pada kelompok sapi yang diberi pakan tambahan Sakura blok sebanyak 300 gr/hari produksi susunya meningkat dari 7,45 kg/ek/hari menjadi 9,34 $\mathrm{kg} / \mathrm{ek} / \mathrm{hari}$ atau meningkat sebesar $20,75 \%$. Sementara Kelompok sapi perah yang mendapat pakan tambahan Sakura blok sebanyak $600 \mathrm{gr} / \mathrm{hr}$ meningkat menjadi $11,17 \mathrm{~kg} / \mathrm{ek} / \mathrm{hari}$ atau meningkat sebesar $33,30 \%$, sedangkan pada kelompok ternak sapi yang mendapat pakan tambahan sebesar $900 \mathrm{gr} / \mathrm{hr}$ justru hanya meningkat menjadi $\quad 10,40 \quad \mathrm{~kg} / \mathrm{ek} / \mathrm{hari}$. Sebagai perbandingan, pada penelitian sapi perah yang diberi Tabut blok sebanyak $450 \mathrm{~g} / \mathrm{blok}$ memproduksi susu lebih tinggi sebesar 2.33 $\mathrm{kg} / \mathrm{ekor} / \mathrm{hari}$ atau $33.1 \%$ lebih tinggi dibandingkan produksi susu sapi perah tanpa diberi Tabut blok, suplemen pakan yang mengandung tapai, temulawak dan bahan lainnya (Sulistyowati dan Erwanto, 2009).

Bentuk lain, konsentrat, yang mengandung bahan sumber asam lemak yang berbeda yang diberikan pada sapi perah, meningkatkan produksi susu sebesar 0,6 kg/ekor/hari dengan konsentrat yang mengandung $4,5 \%$ jagung giling sangrai (Sulistyowati et al., 2010). Jika dihitung berdasarkan nilai ekonomis demplot penggunaan pakan tambahan Sakura blok dapat dilihat pada Tabel 3.

Tabel 3. Studi kelayakan demplot pakan Sakura blok untuk 4 ekor sapi (per bulan).

\begin{tabular}{|c|c|c|c|c|c|c|c|c|}
\hline \multirow{2}{*}{ Uraian } & \multicolumn{2}{|r|}{ D0 } & \multicolumn{2}{|r|}{ D1 } & \multicolumn{2}{|r|}{ D2 } & \multicolumn{2}{|r|}{ D3 } \\
\hline & Vol & Jml (Rp) & Vol & Jml (Rp) & Vol & Jml (Rp) & Vol & Jml (Rp) \\
\hline \multicolumn{9}{|l|}{ Fix cost } \\
\hline Perkandangan (unit) & 1 & 20.000 .000 & 1 & 20.000 .000 & 1 & 20.000 .000 & 1 & 20.000 .000 \\
\hline Cetak blok (paket) & 0 & 0 & 1 & 2.000 .000 & 1 & 2.000 .000 & 1 & 2.000 .000 \\
\hline & & 20.000 .000 & 2 & 22.000 .000 & 2 & 22.000 .000 & 2 & 22.000 .000 \\
\hline \multicolumn{9}{|l|}{ Penyusutan } \\
\hline Perkandangan & & 333.333 & 0 & 333.333 & 0 & 333.333 & 0 & 333.333 \\
\hline Cetak blok (paket) & & 0 & & 55.500 & & 5.500 & & 5.500 \\
\hline \multicolumn{9}{|l|}{ Variable cost } \\
\hline $\begin{array}{l}\text { Rumput (kg)@Rp400 } \\
\text { Sakura blok kg }\end{array}$ & 4200 & 1.680 .000 & 4.200 & 1.680 .000 & 4.200 & 1.680 .000 & 4.200 & 1.680 .000 \\
\hline$@$ Rp.7000 & 0 & 0 & 36 & 252.000 & 72 & 504.000 & 108 & 756.000 \\
\hline Tenaga kerja & 1 & 1.500 .000 & 1 & 1.800 .000 & 1 & 1.800 .000 & 1 & 1.800 .000 \\
\hline OVK & & $\begin{array}{l}200.000 \\
3.380 .000\end{array}$ & & $\begin{array}{l}200.000 \\
3.932 .000\end{array}$ & & $\begin{array}{l}200.000 \\
4.184 .000\end{array}$ & & $\begin{array}{l}200.000 \\
4.436 .000\end{array}$ \\
\hline \multicolumn{9}{|l|}{ Income } \\
\hline $\begin{array}{l}\text { Prod susu } \\
\text { (lt)@Rp10.000 }\end{array}$ & 870 & 8.700 .000 & 1.090 & 10.900 .000 & 1.304 & 13.040 .000 & 1.214 & 12.140 .000 \\
\hline Laba bersih & & 4.986 .667 & 0 & 6.579 .167 & 0 & 8.517.167 & 0 & 7.365 .167 \\
\hline \multicolumn{9}{|l|}{ BEP } \\
\hline Unit (4 ekor sapi) & & 3,76 & & 3,16 & & 2,48 & & 2,86 \\
\hline Omzet (Rupiah) & & 32.706 .767 & & 34.414 .466 & & 32.393 .857 & & 34.667 .705 \\
\hline Lama BEP (bulan) & & 6,56 & & 5,23 & & 3,80 & & 4,71 \\
\hline
\end{tabular}

Catatan : yang dimaksud perkandangan dalam hal ini adalah komplit dengan peralatanya termasuk sarana pemera susu. masa pakai perkkandang 5 tahun dan alat cetak blok 3 tahun. Harga Sakura blok Rp.7000/kg (Tabel 1)

Berdasarkan hasil perhitungan secara ekonomis yang ditujukan pada Tabel 3, demplot penambahan pakan Sakura blok berdampak pada peningkatan pendapatan peternak sapi perah Gapoktan Sumber
Mulya, Kecamatan Kabawetan Kabupaten Kepahiang. Laba bersih yang diperoleh pada penambahan pakan Sakura blok sebesar 600 gr/ekor/hari adalah Rp.8.517.167,-/bulan untuk empat ekor 
sapi. Sementara kelompok ternak yang tidak mendapatkan pakan tambahan Sakura blok hanya menghasilkan laba bersih sebesar Rp.4.986.667,--

Sapi perah yang diberi pakan tambahan Sakura blok sebesar 300 gr/ekor/hari dan 900 gr/ekor/hari masingmasing memperoleh laba bersih sebesar Rp.6.579.167,-- dan Rp.7.365.167,-. Hal ini dapat disimpulkan bahwa pemberian terbaik untuk peningkatan pendapatan yaitu pada demplot penambahan pakan Sakura blok sebanyak 600 gr/ekor/hari.

\section{KESIMPULAN}

Produksi susu tertinggi dihasilkan pada ternak sapi perah yang mendapat pakan tambahan Sakura blok plus 600 gr/ekor/hari yaitu 11,17 kg/ekor/hari, diikuti dengan 10,40 kg/ekor/hari pada kelompot ternak sapi perah yang mendapat Sakura blok 900 gr/ekor/hari dan 9,34 $\mathrm{kg}$ /ekor/hari pada kelompok ternak yang mendapat pakan Sakura blok 300 gr/ekor/hari. Sementara yang tidak mendapat pakan tambahan Sakura blok plus rata-rata produksi susu hanya 7,45 $\mathrm{kg} / \mathrm{ek} / \mathrm{hari}$. Berdasarkan hasil analisis pendapatan, pendapatan tertinggi diperoleh pada ternak sapi perah yang mendapat pakan tambahan 600 gr/ekor/hari yaitu Rp.8.517.167,-/bulan untuk empat ekor sapi. Sementara kelompok ternak yang tidak mendapatkan pakan tambahan Sakura blok hanya menghasilkan labah bersih sebesar Rp.4.986.667,- Sapi perah yang diberi pakan tambahan Sakura blok sebesar 300 gr/ekor/hari dan 900 gr/ekor/hari masing-masing memperoleh laba bersih sebesar Rp.6.579.167,- dan Rp.7.365.167,--.

\section{UCAPAN TERIMAKASIH}

Data dari kegiatan ini dibiayai oleh Hibah KKN- PPM Direktorat Riset dan Pengabdian Masyarakat Direktorat Jendral Penguatan Riset dan Pengembangan Kementrian Riset, Teknologi dan Pendidikan Tinggi No : 031/SP2H/PPM/DRPM/IV/2017 Tanggal 3 A2017. Untuk itu Tim Penulis menyampaikan penghargaan setinggitingginya.

\section{DAFTAR PUSTAKA}

[BSNI]. Badan Standar Nasional Indonesia. 2008. Persyaratan Mutu Bibit Sapi Perah. Departemen Pertanian Indonesia.

Jarmuji, U. Santoso, dan B. Brata. 2013. Suplementasi Sakura Blok untuk Penggemukan Sapi Bali. Laporan Pengabdian Kepada Masyarakat. IPTEKDA LIPI.

Makin, M. 1997. Tatalaksana Peternakan Sapi Perah. Graha Ilmu. Jogjakarta.

Nurdin, E. Manajemen Sapi Perah. Graha Ilmu. Jakarta.

Nurliyani. 2012. Penanganan dan Pengelolahan Susu. PT. Intan Sejati. Klaten. Indonesia.

Santoso, U. 2006. Uji Palatabilitas, Daya simpan dan Kecernaan Sakura Blok pada Kambing Kacang. Laporan penelitian. Universitas Bengkulu.

Sulistyowati, E. dan Erwanto. 2009. Milk Production of Lactating Frisien Holland Crossbred Cows Supplemented with Different Levels of Blok Tabut. Jurnal Pengembangan Peternakan Tropis 34(2):81-87. 
Sulistyowati, E., I. Badarina, dan U. Santoso. 2010. Milk production and modification of milk fatty acid of dairy cows fed PUFA- concentrate. J. of the Indonesian Trop. Anim. Agric. 35(4): 262-267.

Yusdja, Y. dan I. W. Rusastra. 2001. Industri Agribisnis Sapi Perah Nasional Menantang Masa Depan. Jurnal Forum Agro Ekonomi (FAE).
19 (1): 33-42. Pusat Penelitian dan Pengembangan Sosial Ekonomi Pertanian. Bogor.

Yusdja, Y. dan Sajuti. 2002. Skala Usaha Koperasi Susu dan Implikasinya bagi Pengembangan Usaha Sapi Rakyat. Jurnal Agro Ekonomi (JAE). 20 (1): 48-63. Pusat Penelitian dan Pengembangan Sosial Ekonomi Pertanian. Bogor. 